\title{
Quantitative effects of alfalfa extract supply on rice straw degradation, fermentation and biomass synthesis by rumen microorganisms in vitro
}

\author{
Laurent-Philippe BRoudisCoU ${ }^{\mathrm{a} *}$, Ahoefa AGBAGLA-DoHNANI ${ }^{\mathrm{b}}$, \\ Yves PAPON $^{\mathrm{b}}$, Agnès CORNU ${ }^{\mathrm{b}}$, Elisabeth GRENET ${ }^{\mathrm{c}}$, \\ Anne BROUDISCOU ${ }^{\mathrm{d}}$ \\ a UMR INRA-INAPG Physiologie de la Nutrition et Alimentation, \\ 16 rue Claude Bernard, 75231 Paris Cedex 05, Paris, France \\ b Unité de Recherches sur les Herbivores, INRA, 63122 Saint-Genès-Champanelle, France \\ ${ }^{c}$ Département Élevage et Nutrition des Herbivores, 63122 Saint-Genès-Champanelle, France \\ ${ }^{\mathrm{d}}$ Laboratoire de Méthodologie de la Recherche Expérimentale, \\ Université d'Aix-Marseille III, France
}

(Received 4 August 2000; accepted 22 November 2001)

\begin{abstract}
In Asia and Africa, rice straw enters into livestock feeds as the main constituent. It is sometimes associated with fresh legume material, from local garden farming or from legume-cereal rotations, but the possible benefits of this practice need to be estimated more precisely, with special attention to the influence of cytoplasmic contents other than nitrogen or macrominerals on rumen microbial metabolism. In the present study, fresh Medicago sativa extract (AE) was chosen as a model of cytoplasmic contents from tops of tropical legumes such as Vigna unguiculata. It was obtained from whole plants harvested at the beginning of flowering (primary growth). The effects of AE supplementation on a rumen microbial community maintained on a diet made of rice straw and inorganic nitrogen (CP: $\left.73.3 \mathrm{~g} \cdot \mathrm{kg}^{-1} \mathrm{DM}\right)$ were assessed in dual outflow continuous culture. Three input levels were applied in order to detect curvilinear effects: $0,0.227$ and $0.455 \mathrm{ml} \cdot \mathrm{g}^{-1}$ straw DM. The $\mathrm{pH}$ and the redox potential varied from 6.72 to 6.84 , and from -335 to $-370 \mathrm{mV}$ respectively. The addition of $\mathrm{AE}$ had minor effects on fermentation variates. The true degradability of dietary OM and the degradabilities of ash-free NDF and ADF were not modified by AE. Alfalfa extract lowered the outflow of fermented OM (FOM) by $14 \%$ while it enhanced the microbial OM outflow $(+33 \%)$ and the efficiency of microbial protein synthesis ( 15 to $\left.26 \mathrm{~g} \mathrm{~N} \cdot \mathrm{kg}^{-1} \mathrm{FOM}\right)$. This effect was curvilinear, and appeared negligible above $45-50 \%$ of the maximal extract input rate. This legitimised the addition of fresh legume materials to the diet even in small amounts.
\end{abstract}

rumen / rice straw / digestion / protein synthesis / in vitro

* Correspondence and reprints

Tel.: 33 (0)1 44081 759; fax: 33 (0)1 44081 853; e-mail: Laurent.Broudiscou @ inapg.inra.fr 
Résumé - Les effets quantitatifs de l'apport d'extrait de luzerne sur la dégradation de la paille de riz, la fermentation et la synthèse de biomasse par les micro-organismes du rumen in vitro. En Asie et en Afrique, l'affouragement des ruminants en paille de riz est parfois associé à des déchets de maraîchage ou à des légumineuses (Niébé). Les bénéfices éventuels de cette pratique doivent être vérifiés, en portant une attention particulière à l'action des composés cytoplasmiques autres que les protéines et les minéraux majeurs sur le métabolisme des micro-organismes du rumen. Le contenu cytoplasmique du modèle choisi est un extrait par pressage d'une luzerne (Medicago sativa) récoltée en début de floraison (EL). Nous avons étudié l'effet de l'EL sur une communauté de microorganismes du rumen maintenue en fermenteurs à double effluent sur une ration paille de riz + azote inorganique (MAT : $73.3 \mathrm{~g} \cdot \mathrm{kg}^{-1} \mathrm{MS}$ ). Trois niveaux d'apport ont été appliqués pour détecter d'éventuels effets curvilinéaires : $0 ; 0,227 ; 0,455 \mathrm{ml} \cdot \mathrm{g}^{-1} \mathrm{MS}$ paille. Le $\mathrm{pH}$ et le potentiel redox ont varié de 6,72 à 6,84 , et de -335 à $-370 \mathrm{mV}$ respectivement. L'EL n'a pas significativement modifié les variables fermentaires, ni la dégradabilité réelle de la MO, ou les dégradabilités du NDF et ADF déminéralisés. L'extrait de luzerne a diminué le flux de MO fermentée (MOF) de $14 \%$ tandis qu'il a accru le flux de MO microbienne (+33\%) et l'efficacité de la synthèse de protéines microbiennes (de 15 à $26 \mathrm{~g} \mathrm{~N} \cdot \mathrm{kg}^{-1} \mathrm{MOF}$ ). Cet effet a été curvilinéaire et paraît négligeable au delà de $45-50 \% \mathrm{du}$ niveau d'apport maximal. Dans notre essai, l'EL n'a pas significativement modifié l'apport d'énergie et d'azote aux micro-organismes. Son action catalytique sur le métabolisme microbien justifie l'apport de matière végétale fraîche dans la ration même en faible quantité.

rumen / paille de riz / digestion / synthèse protéique / in vitro

\section{INTRODUCTION}

Assessing nutritional strategies for improving rice straw utilisation by ruminants remains a challenging goal in developing countries. The approximate annual world production of rice straw can be estimated from the rice production figures $(408 \mathrm{Mt}$ for $1999 / 2000$ according to the USDA-Foreign Agricultural Service) at 400-800 Mt per year, as the ratio of grain to grain plus straw equals 0.50 with modern varieties and 0.3 with traditional ones [19]. This represents an amount of biomass equivalent to wheat straw. In western countries, where less than $3 \%$ of the rice is produced, rice straw is merely used to provide the dietary fibre fraction necessary for proper functioning of the rumen, most of the digestible energy being brought into the diet by cereals and other concentrates [19]. In Asia and Africa, this roughage enters into livestock feeds as the main constituent. However, when fed alone on a long-term basis, this low-quality roughage is insufficient to meet the animal's maintenance needs. It may then be mixed with fresh plant material, legumes or wastes from vegetables issued from local garden farming. In Sudan, cowpea tops (Vigna unguiculata) have been commercialised as feed supplements for cattle [33]. This legume has also been successfully grown in rotation with Pearl millet in India [15] and a number of cereals in Nigeria [14, 29]. Similarly, Sesbania rostrata and Dolichos lablab have been associated with rice, sorghum and millet in Africa [1]. However, the possible benefits of this practice need to be estimated precisely, with careful attention to the specific influence of plant cytoplasmic compounds other than nitrogen and macrominerals on rumen microbial metabolism.

The aim of the present study was to characterise and quantitate, in vitro, the effects of fresh legume extract supply on the metabolism of a rumen microbial community maintained on a diet made of rice straw and inorganic nitrogen. The use of dual outflow fermenters allowed the simultaneous observation of the degradation of major feed constituents, individual gas and net volatile fatty acid productions, and biomass synthesis by micro-organisms. 


\section{MATERIALS AND METHODS}

\subsection{Experimental scheme}

Alfalfa extract was chosen as a model of cytoplasmic contents because its biochemical composition was similar to Vigna unguiculata from which fresh material was not available in France. Both species exhibit similar ranges of variation for niacin, riboflavin, thiamin, $\beta$-carotene and mineral concentrations in aerial parts [11]. The main difference is the concentration of ascorbic acid which is a factor of three smaller in Vigna unguiculata than in alfalfa. Alfalfa extract did not interfere with the measurement of straw cell-wall fraction degradabilities. Its contribution to the inflow of cell-wall constituents was negligible, below the quantification level permitted by the gravimetric measurements in the NDF-ADF fractionation method.

As the possible effects of legume supplementation were not characterised in the literature, three extract input levels were applied in order to detect curvilinear effects: $0,0.227$ and $0.455 \mathrm{ml} \cdot \mathrm{g}^{-1}$ straw dry matter (DM). The supplementation of rice straw with alfalfa extract corresponded to an incorporation level of whole alfalfa in the diet up to $10 \%$ on a DM basis. The study totalled 12 runs, in 3 seven-day consecutive experimental periods. For each period, the extract inputs were randomly assigned to 3 dual outflow fermenters (working volume of 1.1 litre). On period 3, three testruns with intermediate alfalfa amounts (one at $0.114 \mathrm{ml} \cdot \mathrm{g}^{-1}$ straw DM and two at $0.341 \mathrm{ml} \cdot \mathrm{g}^{-1}$ straw DM) were performed in parallel with the main trial on additional fermenters, to assess the choice of second order polynomials as models of the effects of alfalfa on rumen microorganisms metabolism. The data collected at these test-runs did not participate in the estimation of regression weights.

\subsection{Experimental feeds}

The rice straw (Oryza sativa, variety Thaibonnet) was harvested in the Camargue (Rhône delta) region of France. It was coarsely ground (screen aperture of $8 \mathrm{~mm}$ ) and pelleted (Unité de Préparation des Aliments Expérimentaux, INRA Jouy-en-Josas, France). The DM content was $858 \mathrm{~g} \cdot \mathrm{kg}^{-1}$ $\mathrm{FM}$, and DM composition was $\left(\mathrm{g} \cdot \mathrm{kg}^{-1} \mathrm{DM}\right)$ : organic matter $(\mathrm{OM}) 888$, neutral detergent fiber (NDF) 733, acid detergent fiber (ADF) 428, acid detergent lignin (ADL) 65, crude protein 36.9.

The alfalfa (Medicago sativa) extract was obtained from whole plants harvested at the beginning of flowering (first growth), coarsely chopped and divided into portions of $200 \mathrm{~g}$. These long chop batches were immediately stored in air-tight plastic bags, frozen and kept at $-20{ }^{\circ} \mathrm{C}$ until used. The soluble sugars and crude protein (determined by the Dumas technique) contents of the extract were $12.0 \mathrm{~g} \cdot \mathrm{l}^{-1}$ and $15.9 \mathrm{~g} \cdot \mathrm{l}^{-1}$ respectively. Fresh extract was prepared every incubation day. At $9.00 \mathrm{~h}$, a portion of alfalfa was defrosted and finely chopped in a blender. The extract was squeezed from chopped alfalfa in a stainless steal mechanical press at a rate of $61 \%$ of initial water content. It was kept at $+4{ }^{\circ} \mathrm{C}$ until it was introduced into the fermenters.

\subsection{Incubation procedure}

The three donor animals were ruminallycannulated wethers fed $1200 \mathrm{~g} \cdot \mathrm{d}^{-1}$ rice straw and $100 \mathrm{~g} \cdot \mathrm{d}^{-1}$ soybean meal in two meals with free access to water. The rumen contents used as inoculum were taken after a $24 \mathrm{~h}$ fasting period and processed as in [6]. Each fermenter was maintained at $39^{\circ} \mathrm{C}$ and was continuously infused with artificial saliva whose composition is detailed in [5]. This buffer contained $0.4 \mathrm{~g} \cdot \mathrm{l}^{-1} \mathrm{HCl}-\mathrm{Cys}-$ teine as a reducing agent. The fermentation broths were separately supplemented with $88 \mathrm{mg} \cdot \mathrm{d}^{-1} \mathrm{CaCl}_{2} 2 \mathrm{H}_{2} \mathrm{O}, 42 \mathrm{mg} \cdot \mathrm{d}^{-1} \mathrm{MgCl}_{2}$ 
$4.5 \mathrm{H}_{2} \mathrm{O}$. Eleven grams of pelleted straw (on a DM basis) and $5 \mathrm{ml}$ of a $30.57 \mathrm{~g} \cdot \mathrm{l}^{-1} \mathrm{NH}_{4} \mathrm{Cl}$ solution was supplied to the fermenters at $11.00 \mathrm{~h}$ and $23.00 \mathrm{~h}$. At the same time, the alfalfa extract prepared at $9.00 \mathrm{~h}$ was pipetted into the fermenters $(1.25,2.5,3.75$ or $5 \mathrm{ml}$ per meal). The in vitro dilution rates of particle and liquid phases were set at $0.03 \cdot \mathrm{h}^{-1}$ and $0.06 \cdot \mathrm{h}^{-1}$, respectively. The procedures followed to control the two turnover rates, and for the daily collection of displaced and filtered effluents, were identical to [6].

\subsection{Analytical methods}

After a five-day adaptation term, $10 \mathrm{ml}$ of filtered (pore size of the filters $=200 \mu \mathrm{m}$ ) fermentation broth were taken at $10.00 \mathrm{~h}$ for redox potential and $\mathrm{pH}$ measurement, and subsampled for volatile fatty acids (VFA), ammonia nitrogen $\left(\mathrm{NH}_{3}-\mathrm{N}\right)$ and protozoa population density determination. Protozoa were counted according to [6]. The fermentation gas volume and composition were determined on days 6 and 7 by gas chromatography as described in [4]. The displaced and filtered effluents collected on days 6 and 7 were pooled and subsampled for DM, VFA and $\mathrm{NH}_{3}-\mathrm{N}$ analysis. The samples for VFA and $\mathrm{NH}_{3}-\mathrm{N}$ determination were mixed with 0.1 volume of $\mathrm{H}_{3} \mathrm{PO}_{4} 8.2 \%$ (w/w) and stored at $-20{ }^{\circ} \mathrm{C}$ until processing. $\mathrm{NH}_{3}-\mathrm{N}$ was determined as described by [9]. VFA were determined as described in [3].

On day 7 , the bacterial reference pool for proteosynthesis determination was isolated from the pooled effluents by the following procedure. One litre of fresh total effluent per vessel was adjusted to $\mathrm{pH} 8.0$ with $1 \mathrm{~N} \mathrm{NaOH}$, and homogenised for $3 \times 1 \mathrm{~min}$ in a Waring blender, according to [35]. The feed residue was then separated by centrifugation at $1500 \mathrm{~g}$ for $10 \mathrm{~min}$. The supernatant was centrifuged at $20000 \mathrm{~g}$ for $30 \mathrm{~min}$ to isolate the bacterial fraction. The bacterial pellet was resuspended in $\mathrm{NaCl}$ $\left(9 \mathrm{~g} \cdot \mathrm{l}^{-1}\right)$, centrifuged at $20000 \mathrm{~g}$ for $30 \mathrm{~min}$ and freeze-dried. The remaining effluents were also freeze-dried. Feeds and freezedried effluents were ground prior to analysis using a Culatti grinder with a screen of $0.8 \mathrm{~mm}$ aperture. Feed, effluent and bacterial samples were analysed for DM, OM [7], NDF and ADF [36]. Total nitrogen was measured by the Dumas technique. Effluent and bacterial samples were analysed for nucleobases, used as microbial markers, according to [21] using a diode-array detector (Beckman Instruments, Fullerton).

\subsection{Calculations and statistical analyses}

The daily amount of fermented OM (FOM) was estimated from the relation given by Demeyer and Van Nevel [10] to calculate the amounts of hexoses theoretically fermented (HF).

$$
\begin{aligned}
& \mathrm{HF}\left(\mathrm{mol} \cdot \mathrm{d}^{-1}\right)=(\mathrm{C} 2+\mathrm{C} 3) / 2+\mathrm{C} 4+\mathrm{C} 5 \\
& \mathrm{FOM}\left(\mathrm{g} \cdot \mathrm{d}^{-1}\right)=162 \times \mathrm{HF}
\end{aligned}
$$

where $\mathrm{C} 2, \mathrm{C} 3, \mathrm{C} 4$, and $\mathrm{C} 5$ were the daily outflows $\left(\mathrm{mol} \cdot \mathrm{d}^{-1}\right)$ of acetate, propionate, butyrate and valerate, respectively. The true OM degradability $\left(\mathrm{td}_{\mathrm{OM}}\right)$ was determined from dietary OM inflow and fermented and microbial OM outflows as detailed in [4]. The degradabilities of ash-free NDF and ADF were calculated from the determination of their ash content in quadruplet. The efficiency of microbial protein synthesis (EMPS) was determined by equation (3). $\begin{aligned} \text { EMPS }= & \text { g microbial N daily outflow / } \\ & \text { kg FOM daily outflow. }\end{aligned}$

The results were submitted to a mixedmodel analysis of covariance (ANCOVA) using the MINITAB GLM procedure [22, 34]. Terms in the model were alfalfa supplementation $(\mathrm{Su})$ and period $(\mathrm{Pe})$. The period factor was random and the alfalfa factor was the covariate. Alfalfa sums of squares were partitioned into linear and quadratic effects. The variable $\mathrm{Su}$ was 
coded: it varied from -1 to +1 and was related to the actual amount of alfalfa (A) supplied (in ml per $g$ straw DM), by the equation:

$$
\mathrm{Su}=\mathrm{A} / 0.227-1 \text {. }
$$

For any response, the predicted value $\mathrm{Y}$ for a given level of alfalfa supplementation can be calculated using the corresponding regression weights estimates and the coded variable $\mathrm{Su}$ :

$$
\mathrm{Y}=\mathrm{b}_{0}+\mathrm{b}_{1} \times \mathrm{Su}+\mathrm{b}_{2} \times \mathrm{Su}^{2} .
$$

As an illustration, when alfalfa extract was supplemented at maximal rate, the variable Su was equal to +1 and, according to the coefficients given in Table I the predicted $\mathrm{pH}$ equalled:

$$
\begin{aligned}
\mathrm{pH} & =6.76-0.03 \times \mathrm{Su}+0.01 \times \mathrm{Su}^{2} \\
& =6.76-0.03+0.01=6.74 .
\end{aligned}
$$

The adequacy of second order polynomials to model the action of alfalfa supplementation was preliminarily tested by comparing predicted response values with measured values at three test-runs in period 3, and required to estimate the effect of this specific period on responses. Thus, the experimental results were submitted to multiple linear regression by a MINITAB procedure [22]. The prediction interval for an individual observation was estimated with a $P$-value of $95 \%$. The tables only summarise the results of mixed model ANCOVA.

\section{RESULTS}

Although three test runs constituted a limited validation, their data did not belie the use of second-order polynomials to model the influence of alfalfa extract on the metabolic activity of rumen micro-organ-

\begin{tabular}{|c|c|c|c|c|c|c|c|c|c|c|}
\hline \multirow{2}{*}{\multicolumn{2}{|c|}{ Response }} & \multirow[t]{2}{*}{$\mathrm{pH}$} & \multirow{2}{*}{$\begin{array}{l}\text { Eh } \\
(\mathrm{mV})\end{array}$} & \multicolumn{2}{|c|}{ Protozoa $\left(\mu \mathrm{l}^{-1}\right)$} & \multirow{2}{*}{$\begin{array}{l}\text { VFA } \\
(\mathrm{mM})\end{array}$} & \multicolumn{3}{|c|}{ Molar proportion (\%VFA) } & \multirow{2}{*}{$\begin{array}{l}\mathrm{NH}_{3}-\mathrm{N} \\
\mathrm{mg} \cdot \mathrm{l}^{-1}\end{array}$} \\
\hline & & & & $>70 \mu \mathrm{m}$ & Total & & $\mathrm{C} 2$ & $\mathrm{C} 3$ & $\mathrm{C} 4$ & \\
\hline Source & d.f. & $P>F$ & $P>F$ & $P>F$ & $P>F$ & $P>F$ & $P>F$ & $P>F$ & $P>F$ & $P>F$ \\
\hline $\mathrm{Su}$ & 1 & 0.045 & 0.34 & 0.13 & 0.59 & 0.93 & 0.38 & 0.13 & 0.21 & 0.12 \\
\hline $\mathrm{Su}^{2}$ & 1 & 0.65 & 0.96 & 0.51 & 0.075 & 0.83 & 0.90 & 0.51 & 0.20 & 0.51 \\
\hline $\mathrm{Pe}$ & 2 & 0.098 & 0.10 & 0.087 & 0.093 & 0.23 & 0.19 & 0.56 & 0.09 & 0.002 \\
\hline RSD & 4 & 0.024 & 7.88 & 0.521 & 5.65 & 5.59 & 1.02 & 0.910 & 0.436 & 2.73 \\
\hline \multicolumn{11}{|c|}{ Regression weights } \\
\hline $\mathrm{b}_{0}$ & & $\begin{array}{c}6.76 \\
( \pm 0.014)\end{array}$ & $\begin{array}{l}-346.2 \\
( \pm 4.5)\end{array}$ & $\begin{array}{c}2.33 \\
( \pm 0.30)\end{array}$ & $\begin{array}{c}16.5 \\
( \pm 3.3)\end{array}$ & $\begin{array}{c}56.3 \\
( \pm 3.2)\end{array}$ & $\begin{array}{c}70.8 \\
( \pm 0.59)\end{array}$ & $\begin{array}{c}20.8 \\
( \pm 0.53)\end{array}$ & $\begin{array}{c}7.17 \\
( \pm 0.25)\end{array}$ & $\begin{array}{c}14.0 \\
( \pm 1.6)\end{array}$ \\
\hline $\mathrm{b}_{1}$ & & $\begin{array}{c}-0.03 \\
( \pm 0.010)\end{array}$ & $\begin{array}{c}3.4 \\
( \pm 3.2)\end{array}$ & $\begin{array}{c}0.40 \\
( \pm 0.21)\end{array}$ & $\begin{array}{c}-1.3 \\
( \pm 2.3)\end{array}$ & $\begin{array}{c}0.20 \\
( \pm 2.3)\end{array}$ & $\begin{array}{c}0.41 \\
( \pm 0.42)\end{array}$ & $\begin{array}{c}-0.70 \\
( \pm 0.37)\end{array}$ & $\begin{array}{c}0.26 \\
( \pm 0.18)\end{array}$ & $\begin{array}{c}2.2 \\
( \pm 1.1)\end{array}$ \\
\hline$b_{2}$ & & $\begin{array}{c}0.01 \\
( \pm 0.017)\end{array}$ & $\begin{array}{c}-0.3 \\
( \pm 5.6)\end{array}$ & $\begin{array}{c}-0.27 \\
( \pm 0.37)\end{array}$ & $\begin{array}{c}9.5 \\
( \pm 4.0)\end{array}$ & $\begin{array}{l}-0.93 \\
( \pm 4.0)\end{array}$ & $\begin{array}{c}-0.10 \\
( \pm 0.72)\end{array}$ & $\begin{array}{c}0.47 \\
( \pm 0.64)\end{array}$ & $\begin{array}{c}-0.47 \\
( \pm 0.31)\end{array}$ & $\begin{array}{c}-1.4 \\
( \pm 1.9)\end{array}$ \\
\hline $\mathrm{R}^{2}$ & & 0.81 & 0.71 & 0.77 & 0.79 & 0.53 & 0.61 & 0.58 & 0.78 & 0.96 \\
\hline
\end{tabular}
isms maintained on a rice straw diet as, for most variates, all three values measured in

Table I. ANCOVA results for fermentation pattern.

Eh: redox potential, VFA: volatile fatty acids, $\mathrm{NH}_{3}-\mathrm{N}$ : ammonia-nitrogen, $\mathrm{C} 2$ : acetate, C3: propionate, C4: butyrate, $P>F$ : probability of variance ratio exceeding the tabulated $F$-value, RSD: residual standard deviation. Regression model: Response $=b_{0}+b_{1} \mathrm{Su}+b_{2} \mathrm{Su}^{2}$. 
these test-runs were in accordance with predictions. Only 4 values were out of their prediction interval from a total of 99 , which is statistically expected. They concerned rather minor variates: two associated with the population density of protozoa and two with the productions of isobutyrate and valerate.

\subsection{Characteristics of fermentation broths}

The variates related to fermentation broths at $10.00 \mathrm{~h}$ are given in Table I. The addition of alfalfa extract had minor effects. The $\mathrm{pH}$ and the redox potential varied from 6.72 to 6.84 , and -334.9 to $-369.2 \mathrm{mV}$, respectively, and both ranges were optimal with regard to rumen microbial metabolism. The VFA concentration in the fermentation broths ranged between 45.9 and $63.4 \mathrm{mM}$. The fermentation pattern was characterised by low levels of butyrate. Protozoa numbers varied from 8.4 to $37.2 \mu \mathrm{l}^{-1}$ (and from 1.0 to $3.2 \mu 1^{-1}$ for large species). Alfalfa supplementation linearly influenced a number of variates: it tended to acidify the fermentation broth, to favour large protozoan species ( $+48 \%$ from 0 to $10 \mathrm{ml} \cdot \mathrm{d}^{-1}$ extract), to decrease propionate molar proportion $(-6 \%)$ and to increase $\mathrm{NH}_{3}-\mathrm{N}$ concentration $(+42 \%)$.

\subsection{Energy metabolism}

The true degradability of dietary OM and the degradabilities of ash-free NDF and ADF ranged from 42.9 to $51.6 \%, 34.4$ to $53.5 \%$ and 32.5 to $54.0 \%$, respectively. They were not modified by alfalfa supplementation. On the contrary, the addition of alfalfa extract altered the extent of fermentation (Tab. II). The input of $10 \mathrm{ml} \cdot \mathrm{d}^{-1}$ extract

Table II. ANCOVA results for volatile fatty acid production, daily amounts of hexoses theoretically fermented $(\mathrm{HF})\left(\mathrm{mmol} \cdot \mathrm{d}^{-1}\right)$, and relative productions of acetate $(\mathrm{C} 2)$, propionate $(\mathrm{C} 3)$ and butyrate (C4) (mol·100 $\left.\mathrm{mol}^{-1} \mathrm{HF}\right)$.

\begin{tabular}{|c|c|c|c|c|c|c|c|c|c|c|c|}
\hline \multicolumn{2}{|c|}{ Response } & $\mathrm{C} 2$ & $\mathrm{C} 3$ & IC4 & $\mathrm{C} 4$ & IC5 & $\mathrm{C} 5$ & $\mathrm{HF}$ & $\mathrm{C} 2$ & $\mathrm{C} 3$ & $\mathrm{C} 4$ \\
\hline & & \multicolumn{7}{|c|}{$\left(\mathrm{mmol} \cdot \mathrm{d}^{-1}\right)$} & \multicolumn{3}{|c|}{$\left(\mathrm{mol} \cdot 100 \mathrm{~mol}^{-1} \mathrm{HF}\right)$} \\
\hline Source & d.f. & $P>F$ & $P>F$ & $P>F$ & $P>F$ & $P>F$ & $P>F$ & $P>F$ & $P>F$ & $P>F$ & $P>F$ \\
\hline $\mathrm{Su}$ & 1 & 0.095 & 0.16 & 0.12 & 0.92 & 0.55 & 0.024 & 0.11 & 0.38 & 0.62 & 0.51 \\
\hline $\mathrm{Su}^{2}$ & 1 & 0.26 & 0.80 & 0.31 & 0.26 & 0.34 & 0.22 & 0.61 & 0.16 & 0.15 & 0.17 \\
\hline $\mathrm{Pe}$ & 2 & 0.78 & 0.77 & 0.30 & 0.64 & 0.11 & 0.001 & 0.88 & 0.57 & 0.38 & 0.59 \\
\hline RSD & 4 & 6.23 & 1.53 & 0.067 & 1.30 & 0.024 & 0.014 & 3.92 & 6.66 & 1.56 & 2.66 \\
\hline \multicolumn{12}{|c|}{ Regression weights } \\
\hline $\mathrm{b}_{0}$ & & $\begin{array}{c}53.9 \\
( \pm 3.6)\end{array}$ & $\begin{array}{c}17.4 \\
( \pm 0.88)\end{array}$ & $\begin{array}{c}0.164 \\
( \pm 0.039)\end{array}$ & $\begin{array}{c}7.0 \\
( \pm 0.75)\end{array}$ & $\begin{array}{c}0.170 \\
( \pm 0.014)\end{array}$ & $\begin{array}{c}0.490 \\
( \pm 0.008)\end{array}$ & $\begin{array}{c}43.7 \\
( \pm 2.3)\end{array}$ & $\begin{array}{c}123.2 \\
( \pm 3.8)\end{array}$ & $\begin{array}{c}39.8 \\
( \pm 0.90)\end{array}$ & $\begin{array}{c}16.0 \\
( \pm 0.1 .5)\end{array}$ \\
\hline $\mathrm{b}_{1}$ & & $\begin{array}{c}-5.5 \\
( \pm 2.5)\end{array}$ & $\begin{array}{c}-1.1 \\
( \pm 0.62)\end{array}$ & $\begin{array}{c}0.054 \\
( \pm 0.027)\end{array}$ & $\begin{array}{c}-0.1 \\
( \pm 0.53)\end{array}$ & $\begin{array}{c}0.007 \\
( \pm 0.010)\end{array}$ & $\begin{array}{c}0.020 \\
( \pm 0.006)\end{array}$ & $\begin{array}{c}-3.3 \\
( \pm 1.6)\end{array}$ & $\begin{array}{c}-2.7 \\
( \pm 2.7)\end{array}$ & $\begin{array}{c}0.3 \\
( \pm 0.64)\end{array}$ & $\begin{array}{c}0.8 \\
( \pm 1.1)\end{array}$ \\
\hline $\mathrm{b}_{2}$ & & $\begin{array}{c}5.7 \\
( \pm 4.4)\end{array}$ & $\begin{array}{c}-0.3 \\
( \pm 1.1)\end{array}$ & $\begin{array}{c}0.055 \\
( \pm 0.047)\end{array}$ & $\begin{array}{c}-1.2 \\
( \pm 0.92)\end{array}$ & $\begin{array}{c}-0.018 \\
( \pm 0.017)\end{array}$ & $\begin{array}{c}-0.014 \\
( \pm 0.010)\end{array}$ & $\begin{array}{c}1.5 \\
( \pm 2.8)\end{array}$ & $\begin{array}{c}8.3 \\
( \pm 4.7)\end{array}$ & $\begin{array}{c}-2.0 \\
( \pm 1.1)\end{array}$ & $\begin{array}{c}-3.2 \\
( \pm 1.9)\end{array}$ \\
\hline $\mathrm{R}^{2}$ & & 0.64 & 0.48 & 0.68 & 0.41 & 0.71 & 0.97 & 0.55 & 0.57 & 0.60 & 0.53 \\
\hline
\end{tabular}

$P>F$ : probability of variance ratio exceeding the tabulated $F$-value, RD: residual standard deviation. Regression model: Response $=\mathrm{b}_{0}+\mathrm{b}_{1} \mathrm{Su}+\mathrm{b}_{2} \mathrm{Su}^{2}$. 
lowered daily amounts of hexoses fermented by $14 \%$, mostly through a negative linear influence on the production rate of $\mathrm{C} 2$ $(-17 \%)$. Similarly, this input increased the outflow of minor VFA, isobutyrate (IC4, $+65 \%)$ and $\mathrm{C} 5(+9 \%)$. When expressed in terms of moles per 100 moles of hexoses fermented, the production of the three major VFA was slightly affected by alfalfa in a quadratic manner, the relative output of $\mathrm{C} 2$ being minimal and those of $\mathrm{C} 3$ and $\mathrm{C} 4$ being maximal for intermediate supplies of extract. The output of fermentation gases was not significantly modified by the addition of alfalfa extract, as shown in Table III. Carbon dioxide relative production tended to increase, possibly because of the slight acidification of fermentation broths.

\subsection{Biomass synthesis}

The variates linked to microbial biomass synthesis are presented in Table IV. The
Table III. ANCOVA results for gas production.

\begin{tabular}{|c|c|c|c|c|}
\hline \multirow{2}{*}{\multicolumn{2}{|c|}{ Response }} & \multirow{2}{*}{$\begin{array}{l}\text { Volume } \\
\left(1 \cdot d^{-1}\right)\end{array}$} & \multirow{2}{*}{$\frac{\mathrm{CO}_{2}}{(\mathrm{~mol} \cdot 100}$} & \multirow{2}{*}{$\frac{\mathrm{CH}_{4}}{\left.\mathrm{nol}^{-1} \mathrm{HF}\right)}$} \\
\hline & & & & \\
\hline Source & d.f. & $P>F$ & $P>F$ & $P>F$ \\
\hline $\mathrm{Su}$ & 1 & 0.20 & 0.086 & 0.11 \\
\hline $\mathrm{Su}^{2}$ & 1 & 0.17 & 0.41 & 0.48 \\
\hline $\mathrm{Pe}$ & 2 & 0.047 & 0.24 & 0.20 \\
\hline RSD & 4 & 0.328 & 34.2 & 9.93 \\
\hline \multicolumn{5}{|c|}{ Regression weights } \\
\hline $\mathrm{b}_{0}$ & & $\begin{array}{c}3.30 \\
( \pm 0.19)\end{array}$ & $\begin{array}{c}241 \\
( \pm 19)\end{array}$ & $\begin{array}{c}64.4 \\
( \pm 5.7)\end{array}$ \\
\hline$b_{1}$ & & $\begin{array}{c}0.21 \\
( \pm 0.13)\end{array}$ & $\begin{array}{c}32 \\
( \pm 14)\end{array}$ & $\begin{array}{c}8.4 \\
( \pm 4.1)\end{array}$ \\
\hline$b_{2}$ & & $\begin{array}{c}0.39 \\
( \pm 0.23)\end{array}$ & $\begin{array}{c}22 \\
( \pm 24)\end{array}$ & $\begin{array}{c}5.5 \\
( \pm 7.0)\end{array}$ \\
\hline $\mathrm{R}^{2}$ & & 0.83 & 0.72 & 0.71 \\
\hline
\end{tabular}

$P>F$ : probability of variance ratio exceeding the tabulated $F$-value, RSD: residual standard deviation. Regression model: Response $=\mathrm{b}_{0}+\mathrm{b}_{1} \mathrm{Su}+\mathrm{b}_{2} \mathrm{Su}^{2}$.

Table IV. ANCOVA results for fermented organic matter (FOM) and microbial organic matter outflows (MOM) $\left(\mathrm{g} \cdot \mathrm{d}^{-1}\right)$, true degradability of OM (tdOM), OM partitioning into fermented (Omf) and microbial (OMm) fractions, ash-free NDF and ADF degradabilities, microbial nitrogen daily outflow $(\mathrm{MN})$, and efficiency of microbial protein synthesis (EMPS) $\left(\mathrm{g} \mathrm{N} \cdot \mathrm{kg}^{-1} \mathrm{FOM}\right)$.

\begin{tabular}{|c|c|c|c|c|c|c|c|c|c|c|}
\hline \multirow{2}{*}{\multicolumn{2}{|c|}{ Response }} & FOM & MOM & $\mathrm{tdOM}$ & OMf & $\mathrm{OMm}$ & $\mathrm{dNDF}$ & dADF & \multirow{2}{*}{$\begin{array}{c}\mathrm{MN} \\
\mathrm{mg} \cdot \mathrm{d}^{-1}\end{array}$} & \multirow[t]{2}{*}{ EMPS } \\
\hline & & \multicolumn{2}{|c|}{$\mathrm{g} \cdot \mathrm{d}^{-1}$} & \multicolumn{4}{|c|}{$\%$} & & & \\
\hline Source & d.f. & $P>F$ & $P>F$ & $P>F$ & $P>F$ & $P>F$ & $P>F$ & $P>F$ & $P>F$ & $P>F$ \\
\hline $\mathrm{Su}$ & 1 & 0.11 & 0.008 & 0.43 & 0.09 & 0.009 & 0.71 & 0.79 & 0.038 & 0.008 \\
\hline $\mathrm{Su}^{2}$ & 1 & 0.61 & 0.20 & 0.89 & 0.60 & 0.20 & 0.74 & 0.70 & 0.083 & 0.057 \\
\hline $\mathrm{Pe}$ & 2 & 0.87 & 0.20 & 0.86 & 0.88 & 0.19 & 0.58 & 0.74 & 0.18 & 0.16 \\
\hline RSD & 4 & 0.636 & 0.164 & 3.67 & 3.16 & 0.811 & 7.13 & 7.91 & 10.2 & 1.58 \\
\hline \multicolumn{11}{|c|}{ Regression weights } \\
\hline \multicolumn{2}{|c|}{$\mathrm{b}_{0}$} & $\begin{array}{c}7.08 \\
( \pm 0.37)\end{array}$ & $\begin{array}{c}2.46 \\
( \pm 0.095)\end{array}$ & $\begin{array}{c}47.4 \\
( \pm 2.1)\end{array}$ & $\begin{array}{c}35.2 \\
( \pm 1.8)\end{array}$ & $\begin{array}{c}12.20 \\
( \pm 0.47)\end{array}$ & $\begin{array}{c}46.2 \\
( \pm 4.1)\end{array}$ & $\begin{array}{c}46.4 \\
( \pm 4.6)\end{array}$ & $\begin{array}{c}162.7 \\
( \pm 5.9)\end{array}$ & $\begin{array}{c}23.1 \\
( \pm 0.91)\end{array}$ \\
\hline \multicolumn{2}{|l|}{$\mathrm{b}_{1}$} & $\begin{array}{c}-0.53 \\
( \pm 0.26)\end{array}$ & $\begin{array}{c}0.33 \\
( \pm 0.067)\end{array}$ & $\begin{array}{c}-1.3 \\
( \pm 1.5)\end{array}$ & $\begin{array}{c}-2.9 \\
( \pm 1.3)\end{array}$ & $\begin{array}{c}1.57 \\
( \pm 0.33)\end{array}$ & $\begin{array}{c}-1.2 \\
( \pm 2.9)\end{array}$ & $\begin{array}{c}-0.9 \\
( \pm 3.2)\end{array}$ & $\begin{array}{c}12.7 \\
( \pm 4.2)\end{array}$ & $\begin{array}{c}3.2 \\
( \pm 0.65)\end{array}$ \\
\hline \multicolumn{2}{|l|}{$b_{2}$} & $\begin{array}{c}0.25 \\
( \pm 0.45)\end{array}$ & $\begin{array}{c}-0.18 \\
( \pm 0.12)\end{array}$ & $\begin{array}{c}0.4 \\
( \pm 2.6)\end{array}$ & $\begin{array}{c}1.3 \\
( \pm 2.2)\end{array}$ & $\begin{array}{c}-0.89 \\
( \pm 0.57)\end{array}$ & $\begin{array}{c}-1.8 \\
( \pm 5.0)\end{array}$ & $\begin{array}{c}-2.3 \\
( \pm 5.6)\end{array}$ & $\begin{array}{l}-16.6 \\
( \pm 7.2)\end{array}$ & $\begin{array}{c}-3.0 \\
( \pm 1.1)\end{array}$ \\
\hline \multicolumn{2}{|l|}{$\mathrm{R}^{2}$} & 0.55 & 0.89 & 0.21 & 0.58 & 0.88 & 0.28 & 0.18 & 0.83 & 0.90 \\
\hline
\end{tabular}

$P>F$ : probability of variance ratio exceeding the tabulated $F$-value, RSD: residual standard deviation. Regression model: Response $=b_{0}+b_{1} S u+b_{2} S^{2}$. 
supplementation of fermentation broth with alfalfa extract lowered the outflow of fermented OM $(-14 \%)$ and enhanced the outflow of microbial OM $(+33 \%)$, as shown in Figure 1. This effect was curvilinear, with a decreasing marginal efficiency of alfalfa extract. According to the model, the first millilitre of extract increased the microbial OM output by $0.13 \mathrm{~g} \cdot \mathrm{d}^{-1}$ while the last millilitre increased output only by $0.01 \mathrm{~g} \cdot \mathrm{d}^{-1}$. The addition of alfalfa also shifted the partition of dietary OM in favour of microbial $\mathrm{OM}(\mathrm{OMm})$, to the detriment of fermented $\mathrm{OM}$ (Omf), with no significant variation of undegraded dietary OM fraction.

The outflow of microbial $\mathrm{N}$ and the EMPS varied from 124 to $174 \mathrm{mg} \cdot \mathrm{d}^{-1}$ and from 15.2 to $26.4 \mathrm{~g} \mathrm{~N} \cdot \mathrm{kg}^{-1} \mathrm{FOM}$, respectively. Both variates were increased by alfalfa supplementation in a curvilinear way. According to the model, the EMPS was equal to $17 \mathrm{~g} \mathrm{~N} \cdot \mathrm{kg}^{-1} \mathrm{FOM}$ in the absence of alfalfa. It reached a maximal value of $24 \mathrm{~g} \mathrm{~N} \cdot \mathrm{kg}^{-1} \mathrm{FOM}$ when the extract input rate equalled $7.6 \mathrm{ml} \cdot \mathrm{d}^{-1}$, the first $2.5 \mathrm{ml} \cdot \mathrm{d}^{-1}$ accounting for $55 \%$ in the increase of EPMS. As shown by Figure 2, this can be interpreted in biological terms as a plateau reached at approximately $50 \%$ of the maximal extract input rate.

\section{DISCUSSION}

The introduction of alfalfa extract into the continuous culture systems induced unequivocal changes in a number of microbial functions, which highlighted the mode of action of cytoplasmic contents on the metabolism of rumen microbes maintained on rice straw.

The OM and fibre degradabilities measured with the basal diet belonged to the upper part of the physiological range of variation reported in the literature. For example, NDF and ADF digestibilities of $56.5 \%$ and $51.8 \%$, respectively, were recorded in Ongole $\times$ Holstein dairy cows fed with rice straw ad libitum and $1 \mathrm{~kg} \cdot \mathrm{d}^{-1}$ concentrate [27], while NDF and ADF digestibilities of $73 \%$ were observed in Zebu cows receiving a $80 \%$ rice straw: $20 \%$ cotton seed meal diet at maintenance level [16]. However, our results were consistent with previous

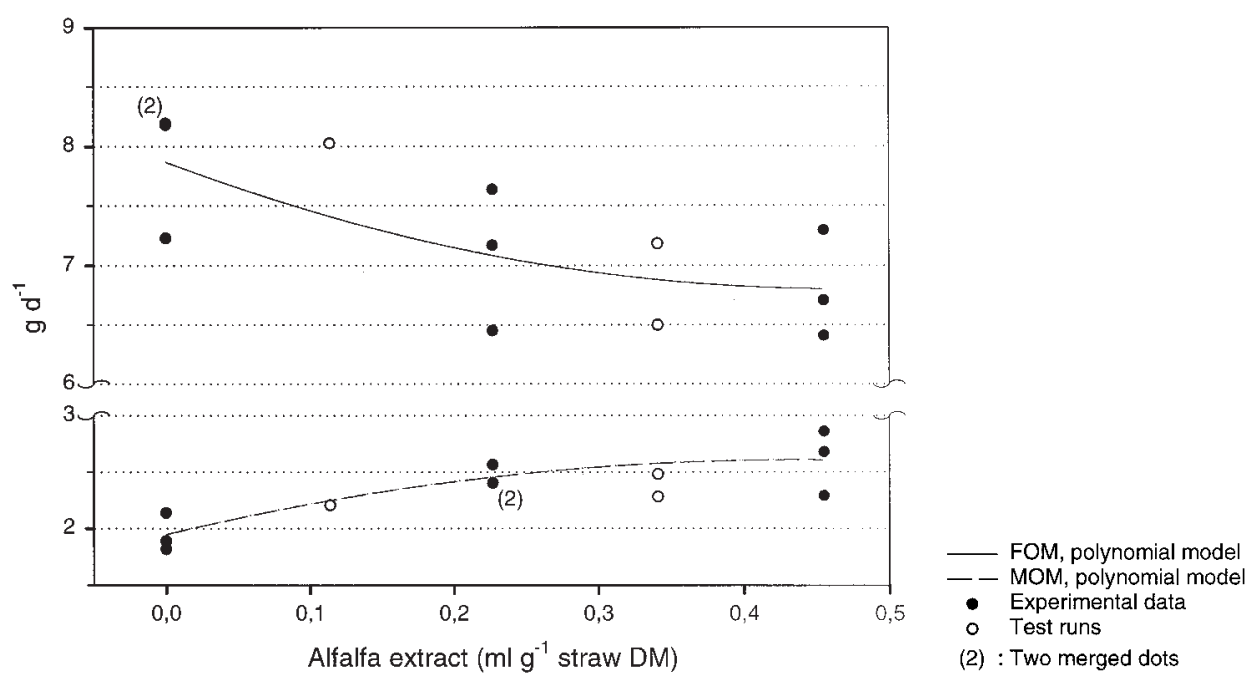

Figure 1. Effect of alfalfa extract on the daily outflows of fermented OM (FOM) and microbial OM (MOM). 

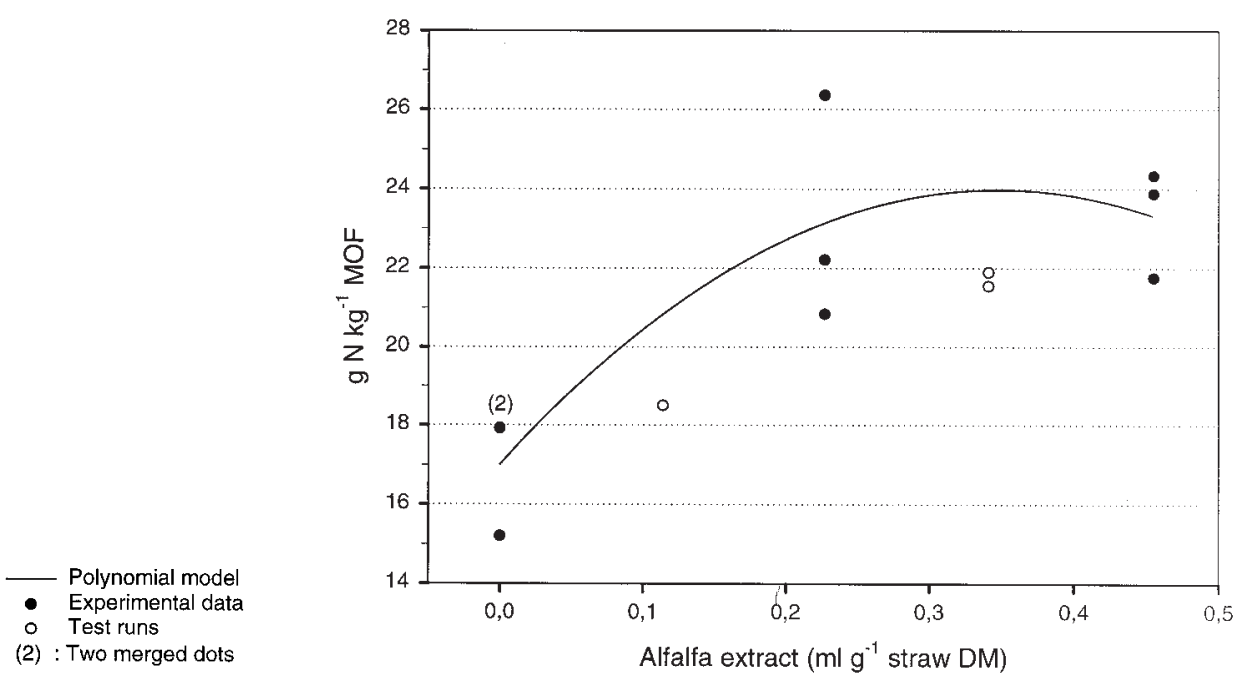

Figure 2. Effect of alfalfa extract on the efficiency of microbial protein synthesis.

reports of in vitro experiments. Using a chemostat culture set at a dilution rate of $0.055 \mathrm{~h}^{-1}$ and fed with a diet made of untreated rice straw: concentrate 75:25, Karunanandaa and Varga measured NDF and ADF degradabilities of $48.0 \%$ and $49.4 \%$ respectively [20]. The straw used in the present work had a composition close to the INRA standard values (in $\mathrm{g} \cdot \mathrm{kg}^{-1} \mathrm{DM}$, OM 850, CP 37, cellulose 367) [2], and within the range of variation reported in the literature [19]. One can only notice the rather low ash content (11.2\% DM), as this constituent varies from 10.4 to $21.8 \% \mathrm{DM}$, with an average value of $16.2 \%$ DM [19]. The high degradability of our straw can be related to two physical characteristics. First, visual inspection of the bales showed that part of the leaves had been lost, probably during raking and baling. The resulting enrichment in culm fraction was consistent with the low mineral content observed as, for rice straw, ash and silica contents in leaves can reach values twice as large as in culms [17, 30, 32]. The reduced leafiness was susceptible to improve the degradability of cell-wall constituents because high levels of silica were associated with lower fibre digestibility $[18,19]$. Moreover, the preliminary grinding and pelleting of straw, which is a necessary process in experiments involving dual outflow fermenters, increased the number of attachment sites for fibredegrading bacteria and was likely to favour bacterial colonisation of straw as this process was to take place on substrate surface, unlike fungal attack which would preferentially progress within the inner layers of roughage biomass [24].

Supplementing rice straw with alfalfa extract did not change the extent of degradation of $\mathrm{OM}$ or fibre. One must stress that the additional amounts of non structural sugars supplied by alfalfa extract can be considered as negligible. It was estimated from published data on alfalfa intracellular carbohydrates [8] that at its maximal rate, alfalfa supplementation supplied the fermentation broth with only $0.4 \mathrm{~g} \cdot \mathrm{d}^{-1}$ starch, $0.1 \mathrm{~g} \cdot \mathrm{d}^{-1}$ sucrose and $0.06 \mathrm{~g} \cdot \mathrm{d}^{-1}$ glucose. Besides, straw cell-wall degradation may have already been maximised by the abovementioned physical characteristics. Alfalfa supplementation may also have enhanced initial fibre hydrolysis rates without 
significantly modifying the overall extent of fibre degradation. As a matter of fact, a lack of improvement of in sacco rumen degradability of rice straw DM in response to supplementation of buffaloes diet with legume straws or protein meals for incubations times exceeding $24 \mathrm{~h}$ has been repeatedly reported [28].

Ammonia concentration in fermenters was quite low, but was consistent with in vivo data [23]. The highest level of alfalfa extract supplementation increased $\mathrm{NH}_{3}-\mathrm{N}$ concentration from 10.4 to $14.8 \mathrm{mg} \cdot \mathrm{l}^{-1}$. The latter value was close to the optimal threshold of $16 \mathrm{mg} \cdot \mathrm{l}^{-1}$ reported to maximise barley straw digestion [25], but we did not observe any significant change in straw cell wall degradation in the present study. Thus, ammonia concentration did not appear to be a limiting factor for microbial metabolism, even for fibrolytic activity, which is known to be sensitive to the supply of ammonia [12]. More generally, the nitrogen content of our experimental diets varied within a narrow range, from 7.33 to $7.94 \% \mathrm{CP}$. Most of this dietary $\mathrm{N}$ (5.89 to $6.52 \% \mathrm{CP}$ ) was readily available for microbes. This clearly shows that alfalfa extracts did not dramatically change nitrogen supply to microorganisms.

Adding alfalfa extract strongly lowered the net outflows of fermented organic matter and resulted in higher microbial biomass yields. We have shown that alfalfa did not significantly modify $\mathrm{N}$ and energy supply to the microbial population in fermenters. Besides, the amounts of phosphorus and sulphur provided by artificial saliva and cysteine were sufficient to meet the microbial metabolic requirements [13]. As the release of hexoses through structural carbohydrate degradation remained unchanged, alfalfa probably restrained the extent of microbial biomass recycling in the fermenters by directly supplying molecules of high metabolic value, such as limiting amino acids, growth factors or coenzymes. When the fermenters were fed on the basal diet, these growth factors had to be synthesised within the microbial community and required the autolysis of a portion of the rumen microbial population to support the completion of the growth cycle of the remaining living microorganisms. Published data on comparable trials are scarce. In an assay implementing the chemostat technique (which means equal solid and liquid retention times), the variates linked to fermentation and biomass synthesis rates from a rice straw: concentrate $75: 25$ diet $(11.2 \% \mathrm{CP})$ clearly had lower values than in the present work. In particular, the EMPS equalled $16.2 \mathrm{~g} \mathrm{~N} \cdot \mathrm{kg}^{-1} \mathrm{FOM}$. Identifying the possible causes of these differences is uneasy. Both assays implemented similar microbial markers, nucleobases in our case and purines in [20]. In our study, the use of nucleobases was justified by the low input of nucleic acids of straw origin and the great susceptibility of alfalfa extract nucleic acids to enzymatic lysis, as suggested by the way MOM and EMPS reacted to alfalfa supplementation. Moreover, taking into account the protozoa bio-volumes, chemical composition and outflow rate reviewed by Williams and Coleman [37], one can estimate from protozoa counts that these microorganisms accounted for less than $2 \%$ of MOM. Thus, the possible discrepancies between the protozoal biomass and microbial reference pools in terms of OM and nucleobase concentrations cannot invalidate our conclusions. A higher EMPS in [20] would also have been expected owing to the shorter retention time for solids ( $18 \mathrm{~h}$ compared to $33 \mathrm{~h}$ in our case), in accordance with chemostat theory, and also to the higher $\mathrm{NH}_{3}-\mathrm{N}$ concentration, along with the dogma of a minimal value of $50-80 \mathrm{mg} \mathrm{NH}-\mathrm{N} \cdot \mathrm{l}^{-1}$ for optimal proteosynthesis [31]. The diet in [20] was more elaborate than our basal treatment as it contained soy bean meal $(14 \% \mathrm{DM})$, a trace mineral premix and a mixture of vitamins A, D and E. Besides the possible consequences of the short straw fibre retention time on the microbial specific composition, these discrepancies may 
partly stress the nutritional importance of additional growth factors present in green plant material.

The most interesting outcome of the present assay is the decreasing marginal efficiency of alfalfa extract on biomass synthesis. In the same way, Prakash et al. investigated the catalytic action of $100 \mathrm{~g} \cdot \mathrm{d}^{-1}$ protein meals on the digestion of rice strawpoultry droppings-rice bran diets by buffaloes [26]. They attributed the higher $\mathrm{N}$ retention and nutrient utilisation with protein meal supplemented diets to a better conversion of rumen ammonia into microbial protein. Our observations confirmed this hypothesis. In our case, this type of relationship between plant extract supplementation and microbial activity legitimised the addition of fresh materials to the diet even in small amounts.

\section{ACKNOWLEDGMENTS}

We wish to thank Mr. Blohorm (Mas d'Agon, France) for the free provision of rice straw, $\mathrm{Mr}$. $\mathrm{X}$. Blanc for processing feeds at the UPEA, Mrs. B. Lassalas, M.-P. Maillot and R. Bergeault for laboratory analyses, and L. L'hotelier for careful management of animals.

\section{REFERENCES}

[1] Allais C., Sesbania rostrata, l'Africaine à la conquête du monde, La Recherche 19 (1988) 672-675

[2] Andrieu J., Demarquilly C., Sauvant D., Tables de la valeur nutritive des aliments, in: Jarrige R. (Ed.), Alimentation des bovins, ovins et caprins, INRA Éditions, Paris, 1988, pp. 352-464.

[3] Broudiscou L.P., Lassalas B., Effects of Lavandula officinalis and Equisetum arvense dry extracts and isoquercitrin on the fermentation of diets varying in forage contents by rumen microorganisms in batch culture, Reprod. Nutr. Dev. 40 (2000) 431-440.

[4] Broudiscou L.P., Papon Y., Broudiscou A., Effects of inorganic nitrogen and amino acids on the degradation of ammonia-treated barley straw and proteosynthesis in a continuous culture of rumen microbes, Anim. Feed Sci. Technol. 77 (1999) 149-162.
[5] Broudiscou L.P., Papon Y., Broudiscou A.F., Optimal mineral composition of artificial saliva for fermentation and methanogenesis in continuous culture of rumen microorganisms, Anim. Feed Sci. Technol. 79 (1999) 43-55.

[6] Broudiscou L.P., Papon Y., Fabre M., Broudiscou A.F., Maintenance of rumen protozoa populations in a dual outflow continuous fermenter, J. Sci. Food Agric. 75 (1997) 273-280.

[7] Broudiscou L., Pochet S., Poncet C., Effect of Linseed Oil Supplementation on Feed Degradation and Microbial Synthesis in the Rumen of Ciliate-Free and Refaunated Sheep, Anim. Feed Sci. Technol. 49 (1994) 189-202.

[8] Castonguay Y., Nadeau P., Lechasseur P., Chouinard L., Differential accumulation of carbohydrates in alfalfa cultivars of contrasting winterhardiness, Crop Sci. 35 (1995) 509-516.

[9] Davies A.W., Taylor K., Application of the autoanalyser in a river authority laboratory, in: Symposium Technicon, Technicon, Tarrytown, 1965, pp. 294-300.

[10] Demeyer D.I., Van Nevel C.J., Methanogenesis, an integrated part of carbohydrate fermentation and its control, in: McDonald I.W., Warner A.C.I. (Eds.), Digestion and metabolism in the ruminant, University of New England Publishing Unit, Armidale, 1975, pp. 366-382.

[11] Handbook of Phytochemical Constituents of GRAS Herbs and Other Economic Plants, CRC Press, Boca Raton, 1992.

[12] Durand M., Conditions for optimizing cellulolytic activity in the rumen, in: Chenost M., Reiniger P. (Eds.), Evaluation of straws in ruminant feeding, Elsevier Applied Science, London, 1989, pp. 3-18.

[13] Durand M., Kawashima R., Influence of minerals in rumen microbial digestion, in: Ruckebusch Y., Thivend P. (Eds.), Digestive physiology and metabolism in ruminants, MTP Press Limited, Lancaster, 1980, pp. 375-408.

[14] Eaglesham A.R.J., Ayanaba A., Rao V.R., Eskew D.L., Mineral $\mathrm{N}$ effects in cowpea and soybean crops on a Nigerian soil. II. Amounts of $\mathrm{N}$ fixed and acccrued to the soil, Plant and Soil 68 (1982) 183-192.

[15] Giri G., De R., Effect of preceding grain legumes on dryland pearl millet in NW India, Exp. Agric. 15 (1979) 169-172.

[16] Grimaud P., Richard D., Vergeron M.P., Guilleret J.R., Doreau M., Effect of drastic undernutrition on digestion in zebu cattle receiving a diet based on rice straw, J. Dairy Sci. 82 (1999) 974-981.

[17] Jackson M.G., Review article: the alkali treatment of straws, Anim. Feed Sci. Technol. 2 (1977) 105-130.

[18] Jackson M.G., Rice straw as livestock feed, World Anim. Rev. 23 (1977) 25-31. 
[19] Juliano B.O., Rice hull and rice straw, in: Juliano B.O. (Ed.), Rice: Chemistry and Technology, American Association of Cereal Chemists, Inc., St Paul, 1985, pp. 689-755.

[20] Karunanandaa K., Varga G.A., Colonization of rice straw by white-rot fungi (Cyathus stercoreus): Effect on ruminal fermentation pattern, nitrogen metabolism, and fiber utilization during continuous culture, Anim. Feed Sci. Technol. 61 (1996) 1-16.

[21] Lassalas B., Jouany J.-P., Broudiscou L., Dosage des bases puriques et pyrimidiques par chromatographie liquide à haute performance, Ann. Zootech. 42 (1993) 170-171.

[22] Minitab, User's Guide 2: Data Analysis and Quality Tools, Minitab Inc., State College, 1998.

[23] Nguyen van Thu, A study of feed degradability and rumen environment of swamp buffaloes, Livest. Res. Rural Dev. 9 (1997) 1-4.

[24] Orpin C.G., Joblin K.N., The rumen anaerobic fungi, in: Hobson P.N., Stewart C.S. (Eds.), The rumen microbial ecosystem, Chapman \& Hall, London, UK, 1997, pp. 140-195.

[25] Orskov E.R., Protein Nutrition in Ruminants, Academic Press, London, 1982.

[26] Prakash P., Reddy D.V., Ramachandra Reddy R., Krishna N., The catalytic effect of supplementation of protein meals on utilization of rice straw-poultry droppings-rice bran diet in buffaloes, Anim. Feed Sci. Technol. 63 (1996) 229-243.

[27] Prasad R.D.D., Reddy M.R., Reddy G.V.N., Effect of feeding baled and stacked urea treated rice straw on the performance of crossbred cows, Anim. Feed Sci. Technol. 73 (1998) 347-352.

[28] Reddy D.V., The effect of supplementation of legume straws on utilisation of rice straw poultry droppings rice bran fish meal based diet in buffaloes, Anim. Feed Sci. Technol. 69 (1997) 305-314.
[29] Reddy K.C., Visser P., Buckner P., Pearl millet and cowpea yields in sole and intercrop systems, and their after-effects on soil and crop productivity, Field Crops Res. 28 (1992) 315-326.

[30] Sannasgala K., Jayasuriya M.C.N., Effect of the physiological and morphological characteristics on chemical composition and in vitro digestibility of different varieties of rice straws, in: Doyle P.T. (Ed.), The utilization of fibrous agricultural residues as animal feeds, University of Melbourne, Parkville, 1984, pp. 47-53.

[31] Satter L.D., Slyter L.L., Effect of ammonia concentration on rumen microbial protein production in vitro, Brit. J. Nutr. 32 (1974) 194-208.

[32] Shen H.Sh., Ni D.B., Sundstøl F., Studies on untreated and urea-treated rice straw from three cultivation seasons: 1 . Physical and chemical measurements in straw and straw fractions, Anim. Feed Sci. Technol. 73 (1998) 243-261.

[33] Sissoko K., Bakker E.J., Dembélé N., Quak W., Touré M., Définition, description et analyse économique partielle des activités d'élevage en zone Soudano-Sahélienne : Cas de la production de viande bovine, Rapports PSS n ${ }^{\circ}$, Wageningen, 1995.

[34] Snedecor G.W., Cochran W.G., Statistical Methods (Méthodes Statistiques), 6th ed., Ames: Iowa State University Press, 1957.

[35] Trabalza-Marinucci M., Poncet C., Fonty G., The effectiveness of some physical and chemical treatments used to remove microorganisms from rumen feed particles, Proc. Soc. Nutr. Physiol. 3 (1994) 188.

[36] Van Soest P.J., Wine R.H., Use of detergent in the analysis of fibrous feed. IV. Determination of plant cell-wall constituants, J. AOAC Int. 50 (1967) 50-55.

[37] Williams A.G., Coleman G.S., The Rumen Protozoa, Springer-Verlag, New York, 1992.

To access this journal online: www.edpsciences.org 